\title{
Decomposing the cascade of uncertainty in risk assessments for urban flooding reflecting critical decision-making issues
}

\author{
Halsnæs, Kirsten; Kaspersen, Per Skougaard
}

Published in:

Climatic Change

Link to article, DOI:

$10.1007 / \mathrm{s} 10584-018-2323-y$

Publication date:

2018

Document Version

Publisher's PDF, also known as Version of record

Link back to DTU Orbit

Citation (APA):

Halsnæs, K., \& Kaspersen, P. S. (2018). Decomposing the cascade of uncertainty in risk assessments for urban flooding reflecting critical decision-making issues. Climatic Change, 151(3-4), 491-506.

https://doi.org/10.1007/s10584-018-2323-y

\section{General rights}

Copyright and moral rights for the publications made accessible in the public portal are retained by the authors and/or other copyright owners and it is a condition of accessing publications that users recognise and abide by the legal requirements associated with these rights.

- Users may download and print one copy of any publication from the public portal for the purpose of private study or research.

- You may not further distribute the material or use it for any profit-making activity or commercial gain

- You may freely distribute the URL identifying the publication in the public portal

If you believe that this document breaches copyright please contact us providing details, and we will remove access to the work immediately and investigate your claim. 


\title{
Decomposing the cascade of uncertainty in risk assessments for urban flooding reflecting critical decision-making issues
}

\author{
Kirsten Halsnæs ${ }^{1} \cdot$ Per Skougaard Kaspersen ${ }^{1}$ (D) \\ Received: 29 November 2017 / Accepted: 30 October 2018 / Published online: 14 November 2018 \\ (C) Springer Nature B.V. 2018
}

\begin{abstract}
Climate change risk assessments traditionally follow an analytical structure in which climate information is linked to impact models, and subsequently to damage models and decisionmaking tools. This structure generates a wide cascade of uncertainties that accumulate with each analytical step, consequently resulting in a wide range of risk estimates. This cascade of uncertainties can suggest that climate change risk assessments are not very useful in the context of decision-making regarding climate adaptation. However, many of the uncertainties revealed in traditionally structured climate risk assessments are not equally relevant to specific decisions, and presenting wide cascades of uncertainties can mask key decision-making parameters. In this paper, we show how the cascade of uncertainty relevant to decisionmaking can be reduced by applying an uncertainty decomposition approach, which, in study design, initially identifies the uncertainty cascade elements of particular relevance to the focal decision-making context. We compare the full cascade of uncertainties that emerge in a traditional risk assessment based on linked climate scenarios, impact modeling, and damage cost assessment with the uncertainty cascade generated by a detailed assessment of urban flooding risks where the focus is on key uncertainties in decision-making on climate change adaptation. A case study on flooding from extreme precipitation in the Danish city of Odense is used to decompose major sources of uncertainties in the climate modeling, the hydrological modeling, and the damage cost assessment. The decomposition approach reduces the focal range of damage cost estimates by 7-9 M EUR, which corresponds to a 20-24\% reduction in the full uncertainty range without the application of the decomposition approach. Assuming that damage cost assessments can provide an indication of how much society should be willing to spend on climate adaptation, a decomposition approach as presented here could assist decision-makers in increasing the economic effectiveness when investing in protective measures.
\end{abstract}

Electronic supplementary material The online version of this article (https://doi.org/10.1007/s10584-0182323-y) contains supplementary material, which is available to authorized users.

Per Skougaard Kaspersen pskk@dtu.dk

1 Climate Change and Sustainable Development (CCSD) Research Group, Department of Management Engineering, Technical University of Denmark, 2800 Kgs. Lyngby, Denmark 


\section{Introduction}

Increasing occurrences of and losses from flooding during extreme weather events in recent decades have assisted in shifting the attention and resources of decision-makers toward a stronger focus on climate change adaptation. This includes responding to the impacts of current flood events by increasing investments in adaptive solutions and reducing vulnerabilities (Munich 2017; European Environment Agency 2017; Climate Policy Initiative 2017). Deciding on the most appropriate measures from an economic and social perspective requires detailed information from several scientific disciplines, including climate science, hydrology, engineering, geography, and economics. The multidisciplinary character of such climate risk assessments accordingly introduces various methodological and practical challenges.

Climate change risk analyses are surrounded by large uncertainties emerging from individual components of the assessment, including climate models, impact models, and damage cost models. Together, these generate a cascade of uncertainties that accumulate with each step in the analysis (Schneider 1983; Moss and Schneider 2000; Wilby and Dessai 2010; Van den Hoek et al. 2014). A major source of uncertainty in climate risk assessments is related to climate modeling and climate scenarios: in particular, the probability of extreme precipitation events is uncertain (Hawkins and Sutton 2009, 2011; Weitzman 2011; Field et al. 2012; Madsen et al. 2017; Zhang et al. 2017). Other key uncertainties facing decision-making in relation to urban pluvial flooding are related to the downscaling of precipitation to relevant geographical scales and to valuations of damage to city assets (e.g., buildings, industry, transport, ecosystems, health, and cultural and historical assets). Hydrological models used for flood hazard mapping and damage cost models introduce additional levels of uncertainty (Wilby and Dessai 2010; Jongman et al. 2012). Taken together, all this forms the basis for a very wide range of risk estimates (Hawkins and Sutton 2011; Cubasch et al. 2013; Halsnæs et al. 2015). Accordingly, this can suggest that flood risk assessments are unreliable and that the technical basis for decision-making on climate adaptation should consequently be considered weak. However, many of the uncertainties revealed in traditionally structured climate risk assessments are not equally relevant to specific decision-making issues.

Uncertainties are commonly quantified and presented in relation to projections of biophysical parameters such as temperature and precipitation (Stocker et al. 2013). In addition, several authors have recently estimated and compared the importance of major drivers of uncertainties over time in these projections, including uncertainties stemming from natural variation, climate scenarios, and climate models (Hawkins and Sutton 2009, 2011; Kent et al. 2015; Santos et al. 2016; Fereday et al. 2018). However, to the best of our knowledge, there is limited literature quantitatively examining the importance of uncertainties in the full range of integrated risk assessments, from climate projections and impact assessments at one end to economic valuation and decision-making criteria at the other. Halsnæs et al. (2015) reveals a cascade of uncertainties by conducting a sensitivity analysis on key input variables in pluvial flood risk assessments, including climate scenarios, damage, and economic assumptions. The study shows that expectations regarding future climate change and economic assumptions are equally important in determining the output of the risk assessment. In decomposing the cascade of uncertainties, it is shown that uncertainties and alternative assumptions applied to the risk assessment chain result in a very large variation in risk estimates regarding pluvial flooding, for example, of $1-85 \mathrm{M} € / \mathrm{y}$ for a medium-size city in Denmark. This suggests that using such risk estimates as a basis for adaptation decision-making calls for further analysis in which uncertainties are treated as particularly important. 
In this paper, we are developing and applying an uncertainty decomposition approach, which in study design initially identifies the uncertainty cascade elements of particular relevance to the focal decision-making context. This approach is used in a case study of flooding from extreme precipitation in the Danish city of Odense. We investigate the uncertainties associated with the time horizon of climate projections and demonstrate how uncertainties relevant to decision-making on adaptation measures can be reduced through the application of detailed context-specific hydrological models and damage cost data for the Danish case study. We demonstrate that the selection of relevant context-specific uncertainties can be used to narrow the climate scenario range and the parameter range in the hydrological and damage cost modeling, thereby helping reduce the cascade of uncertainties presented to decision-makers.

\section{Methods}

\subsection{Risk assessment framework}

In the context of the uncertainty framework presented in this paper, climate change risks are defined as the probability of a specific climate event multiplied by the consequences of the event, as shown in Eq. (1):

$$
\text { Risks }=\text { damages of the event } \times \text { probability of the event }
$$

This also means that the avoided costs of climate change in terms of risk depend on the level of damage and the probability of a given event. ${ }^{1}$

The risks of an event such as urban flooding are thus based on a combination of information from downscaled climate model outputs and spatially explicit assessments of impacts and damage costs. In the cost assessment, the consequences are based on the value of the assets that are expected to be affected by climate events. The perspective of the damage cost assessment in our approach is that of social welfare, ${ }^{2}$ where the total damage costs are an aggregate measure of the costs to all individuals, total damage being calculated as the sum of the damage in all sub-categories.

Our methodology is based on a very data-intensive spatial representation of potentially flooded areas and assets. It therefore requires modeling groups and experts from different scientific disciplines to share outputs and data, given the multidisciplinary character of risk and adaptation studies. An analytical structure for climate change risk assessments of urban flooding is presented in Fig. 1. The analysis starts with detailed downscaled information on current and future climate extremes. Then flood hazard mapping is conducted (e.g., using hydrological models) to identify potentially flooded areas and is combined with detailed information about the location and characteristics of physical assets and socio-economic variables. This provides the basis for calculating damage losses and risks, which are important in assessing and deciding on appropriate and cost-effective adaptation measures. A main objective of the geographically detailed integrated modeling is to assess location-specific flooding and damage costs as a basis for decision-making regarding cost-effective adaptation measures. Some central models and methods include approaches to the parameterization

\footnotetext{
${ }^{1}$ A climate event should be understood here as a broad term covering particular weather events like hot spells, intensive precipitation, and wind storms, which are associated with social risks.

${ }^{2}$ Social welfare reflects societies' perspectives, for example, in relation to climate change impacts.
} 


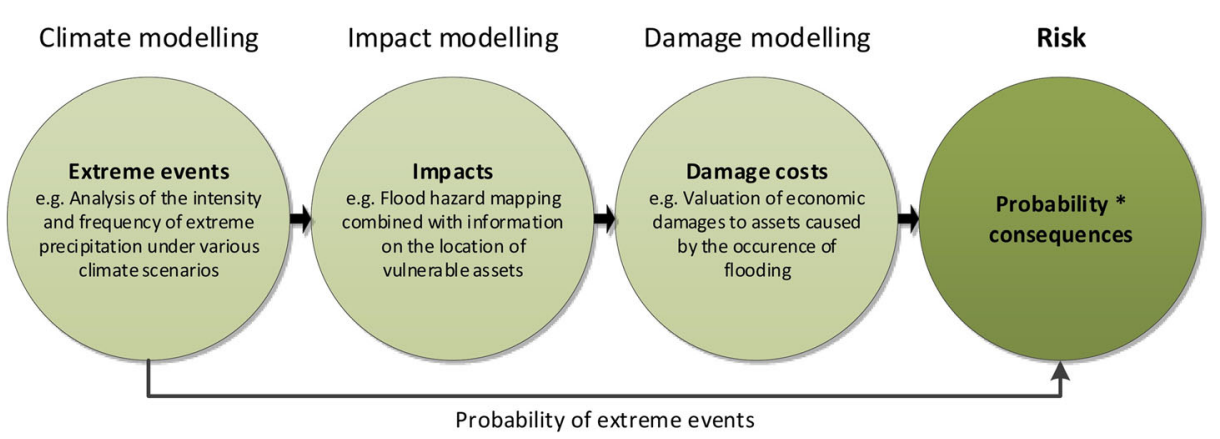

Fig. 1 Analytical structure of climate change risk assessments of urban flooding

(intensity/frequency) and downscaling of climate extremes from large-scale climate models, impact modeling (e.g., hydrological modeling), economic valuations, and damage cost assessment modeling. A more detailed description can be found in Halsnæs et al. (2015) and Kaspersen and Halsnæs (2017).

\subsection{Decomposing the cascade of uncertainties}

In the following, we outline the uncertainty decomposing approach. Starting from the concept of a cascade of uncertainties, Fig. 2 shows how uncertainties evolve in relation to pluvial flood damage when climate scenarios, hydrological models, and damage models are combined. However, not all the uncertainties revealed in "traditional" climate impact assessments are equally relevant to decision-making, and an important aim of the uncertainty decomposition is to narrow the uncertainty range of risk estimates by examining the critical assumptions in a

\section{Full cascade of uncertainty}

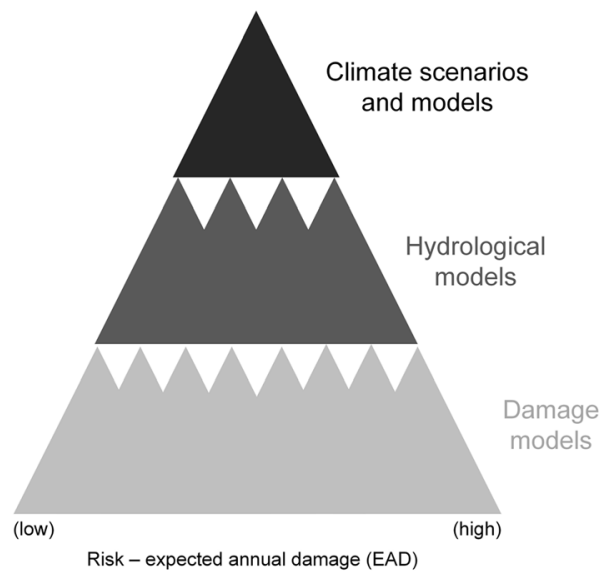

Range

\section{Reduced cascade of uncertainty}

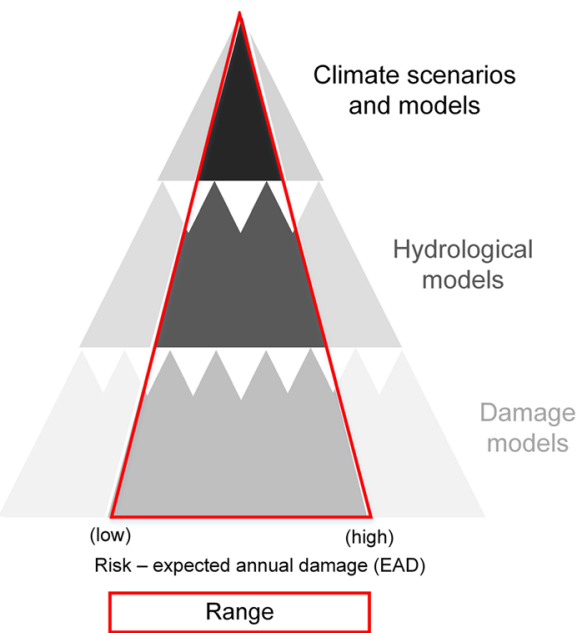

Fig. 2 a Full cascade of uncertainties, measured as the variation in risk estimates when using different assumptions regarding climate change scenarios and models, hydrological models, and damage models. b Reduced cascade of uncertainties and range of focal risk estimates when using the decomposition approach to reduce range of uncertainties relevant to a decision-making context (the area surrounded by red lines shows the focal range of damage) 
specific decision-making context. Our approach is inspired by Wilby and Dessai (2010), who suggest structuring the assessment around critical decision-making issues and address large uncertainties in climate scenarios by suggesting robust adaptation measures. We will elaborate further on how an approach focused on decision-making and the uncertainty cascade can include a context-specific selection of relevant uncertainties in relation to decision-making on adaptation measures targeting urban flooding. The case study is developed to demonstrate how the focal range of uncertainties can be reduced in all elements of the risk assessment, including climate modeling, hydrological modeling, and damage cost modeling.

Figures $2 \mathrm{a}$ and $\mathrm{b}$ show a full cascade of uncertainties and a reduced cascade of uncertainties respectively, to be achieved through a selection of scenario and model assumption combinations that are particularly relevant to decision-making as contextualized by our urban flooding case study. For example, the reduced range of focal uncertainties can be obtained by focusing the risk assessment on specific risks and adaptation options, which can help to select the appropriate time scale of the analysis and to specify the geographical resolution of the flooding and damage cost assessment. We present an example of a reduced cascade of uncertainties in the results section. The analytical "flow" in Fig. 2 is vertical, and the cascade of uncertainties emerges when information from climate scenarios and models, hydrological models, and damage models is combined. There are also, however, uncertainties within each of the three elements (climate scenarios and models, hydrological models, and damage models). The analysis therefore also includes elements of horizontal uncertainty. Here, we have used a terminology reflecting the fact that this paper focuses on urban flooding risks, but the approach illustrated in Fig. 2 has a generic character and can be applied to risk assessments for various climate events. In the following, we provide examples of how to address climate scenario and climate model uncertainties, as well as horizontal uncertainties related to the hydrological and damage modeling of flooding events based on our case study of extreme precipitation in Odense.

Our analysis of flooding in Odense is an example of the selection of key uncertainty ranges based on relevance to the decision-making context. In addition, we are adding a new element in terms of uncertainty analysis for key modeling elements, recognizing that narrowing the uncertainty range enables a more detailed analysis of key modeling assumptions. Here, the focus is on the uncertainty ranges of damage cost estimates. In the case study, we therefore demonstrate how the selection of climate scenarios and of structural improvements to hydrological modeling and damage cost models based on very detailed local spatial information can reduce uncertainties. We will assess how the time horizon of the climate scenarios influences the uncertainty range of damage estimates in relation to climate scenarios and model uncertainties. Then, using the Odense case study, we will focus on alternative assumptions regarding infiltration capacity (hydrological model uncertainty) in different parts of the Odense city area. Finally, the damage model used in the case study uses alternative values for damage to flooded buildings. Altogether, the uncertainties are thus reduced by excluding inferior scenarios, data and model combinations.

\section{Results}

\subsection{Case study area}

The city of Odense is the third largest city in Denmark, with a population of about 200,000 as of September 2016 , and it covers an area of $\approx 100 \mathrm{~km}^{2}$. It consists of a mixture of continuous 
and discontinuous residential areas and industrial and recreational zones, surrounded by agricultural areas and small patches of forest and wetland. It has a unique historic city center with old buildings and churches. Odense is exposed to flooding from both extreme precipitation and storm surges due to its relatively high degree of urban fabric (i.e., large areas of impervious surfaces) (Kaspersen et al. 2015), along with a location close to the sea and the Odense river, which runs right through the city center.

\subsection{Climate modeling and scenarios}

The current analysis includes an assessment of how the decision-making-relevant cascade of uncertainties related to climate model projections is influenced by the time horizon of the analysis. We use two climate scenarios in the assessment to represent a low- and a high-end range of future climate change impacts. The low end is represented by the Representative Concentration Pathway (RCP) 4.5 for the analysis, which represents a scenario close to the temperature target of a $1.5-2{ }^{\circ} \mathrm{C}$ increase in global temperatures set by recent international agreements at COP21 in Paris in 2015 and COP22 in Marrakech in 2016. For this reason, RCP4.5 is likely to become part of "planning scenarios" for many decision-makers in local and national administrations. The high end is represented by RCP8.5, which illustrates how the expected changes in extreme precipitation and subsequently the range of uncertainties could be influenced by a continuation of current GHG emission trends (Sanford et al. 2014). The RCP4.5 scenario describes a future with a global increase in the near-surface air temperature of $1.8^{\circ} \mathrm{C}\left(1.1-2.6^{\circ} \mathrm{C}\right)$ toward 2100 , while the RCP8.5 scenario represents a world where the increase in radiative forcing suggests an increase of $3.7^{\circ} \mathrm{C}\left(2.6-4.8^{\circ} \mathrm{C}\right)$ in 2100 (Meinshausen et al. 2011; Intergovernmental Panel on Climate Change 2014).

To assess the expected change in high-intensity precipitation, an extreme value analysis was conducted using a change factor methodology to calculate the relative difference in maximum hourly precipitation intensities between present-day (1986-2005) and future periods (20162035, 2046-2065, 2081-2100) (Fig. 3). Using a partial duration series (PDS) method, three extreme events per year were selected to derive the extreme value data series used to calculate the change factors following Sunyer et al. (2015). The intensity of different return periods is estimated by fitting a generalized Pareto distribution (GPD) to the extreme data series. Through an analysis of the change factors for the individual grid cell covering Odense and the surrounding grid cells, we observed a large variation in change factors, and we therefore decided to rely on the average change factors for Denmark to avoid selecting an abnormal high/low change factor for further analyses. The presented change factors are therefore averages of the 41 grid cells covering Denmark. Skougaard Kaspersen et al. (2017) provides more information on how the extreme value analysis was conducted. General information on the change factor methodology used in estimating changes in extreme precipitation caused by climate change can be found in Willems et al. (2012) and Sunyer et al. (2015).

Figure 3 shows how the range in the cascade of uncertainties for extreme precipitation develops over time for two different climate scenarios applied to Denmark, the RCP4.5 and the RCP8.5. The change factors were estimated from ten regional climate projections (from the CORDEX archive), which are based on ten different general circulation models (GCMs) and are regionally downscaled to a 50-km resolution by the RCA4 regional climate model (RCM). The inclusion of ten climate projections in the study, rather than a wider range of projections, reflects our aim of providing a simple representation of our methodological approach. In this way, we aim to provide insights into the particular relevance of the cascade of the uncertainties 


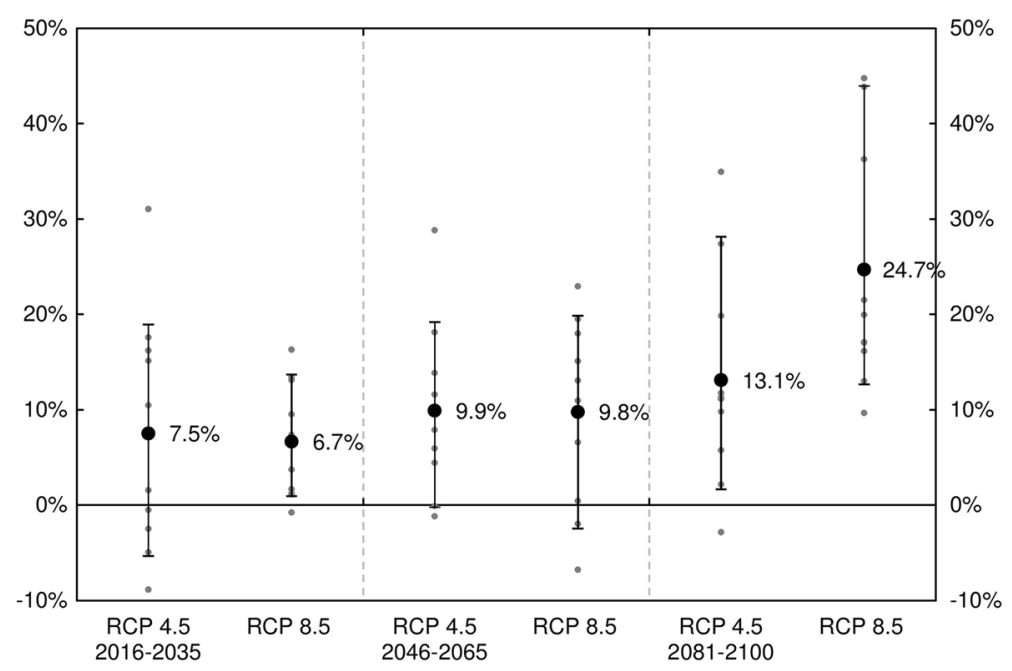

Fig. 3 Changes in the intensity of extreme precipitation in 2016-2035, 2046-2065, and 2081-2100 for Denmark under the RCP 4.5 and RCP 8.5 scenarios (\%) relative to the present day (1986-2005). The data give the average change in intensity for hourly maximum precipitation with return periods of 5-100 years (i.e., average of RP5, RP10, RP20, RP50, and RP100). Results are shown for RCP averages for all ten GCMs (black dots) and for individual GCMs (small gray dots). The results are based on regional climate projections using RCA4 regional climate model downscaling of ten different GCMs: CANESM2, CSIRO, CERFACS, ICHEC, IPSL, MIROC, MOHC, MPI, NCC, and NOAA (ESGF 2016). The error bars show the range within the 10th and 90th percentiles

to decision-making, rather than presenting accurate estimates of the probability of future extreme precipitation events. This implies that the range of climate factors presented does not represent the full range which could be derived from a combination of a large number of GCMs and RCMs. As a result, the range of the resulting risk estimates does not represent a full range.

The results presented in Fig. 3 show the average changes in intensity for maximum hourly precipitation with return periods of 5, 10, 20, 50, and 100 years.

As shown in Fig. 3, we observe a change of - 5-19\% (combined range of RCP 4.5 and 8.5 within 10th and 90th percentiles) in the intensity of extreme precipitation in the short time horizon (2016-2035), and -2-20\% and 13-44\% toward 2046-2065 and 2081-2100 respectively. Comparable changes are projected for RCP 4.5 and RCP 8.5 in the short and medium terms while the intensity is projected to increase the most under the RCP 8.5 scenario in the long term (average changes of $6.7 \%, 9.8 \%$, and $24.7 \%$ for RCP 8.5 in the short, medium, and long terms and $7.5 \%, 9.9 \%$, and $13.1 \%$ for RCP 4.5$)$. We find that the variation between climate models and scenarios increases with the time horizon, with larger differences in projected changes in the long term compared with the short term. In addition, there is only a limited overlap in the long-term projections of changes in extreme precipitation between RCP 4.5 and the RCP 8.5 based on the ten modeling alternatives. In the short term (2016-2035), the difference between the projections of change in extreme precipitation in the two RCPs is relatively small. The small difference in projected changes for RCP 4.5 and RCP 8.5 confirms that the internal climate variability and model uncertainty is stronger than the climate change signal for extreme precipitation toward the middle of the twenty-first century while the degree of climate change becomes increasingly important in the longer terms in line with Hawkins and Sutton (2011) and Maraun (2013). 
In cases where the short- to medium-term analysis (2016-2065) of urban flooding from extreme precipitation is the major decision-making focus, climate scenario uncertainty ranges from a -2 to $20 \%$ increase in the intensity of extreme precipitation (Fig. 3). The range increases considerably to $13-44 \%$ when extending the analysis toward the end of the twenty-first century. The findings presented here clearly illustrate that the time horizon is of major importance for the range of expected changes in extreme precipitation and therefore for decision-making in relation to climate change adaptation. For example, adaptation measures with lifetimes $<50$ years "only" or measures that can be scaled up over time both flexibly and at low cost could be designed for a maximum change in intensities of $20 \%$ (representing the high end of the climate scenarios for the 2016-2065 time perspective), while more inflexible measures with longer lifetimes could be designed for larger increases in precipitation intensities. Examples of flexible adaptation options (options that can be redesigned over time) to cope with pluvial flooding hazards in urban areas include green/blue solutions, systems to separate rainwater and sewage water, surface drainage channels etc., while less flexible adaptation measures include enlarged sewage pipes. It should be recognized here that the choice of flexible adaption measures could offer several benefits, in addition to reducing the consequences of uncertain climate projections, as this can also reduce uncertainties over future flooding damage costs evolving from future urban development (Haasnoot et al. 2013). It should be noted that the uncertainty range considered depends on the variation in the RCPs and the models in the ensemble. This does not address all aspects of the larger specific uncertainties related to projections of extreme precipitation events in the short term, as discussed by Hawkins and Sutton (2011).

\subsection{Hydrological modeling}

A simple overland flow model (MIKE 21-DHI) is applied to simulate the occurrences of extreme precipitation events with a return period (RP) of a hundred years under different climate change scenarios and time horizons for the city of Odense (DHI 2017). We conducted 13 different simulations with variations in precipitation intensities, corresponding to highintensity precipitation with maximum precipitation intensities of 42.9 to $61.4 \mathrm{~mm} / \mathrm{h}$ and total precipitation of 59.1 to $84.6 \mathrm{~mm}$ over a total duration of $4 \mathrm{~h}$ of precipitation. Fig. S1 in the supplementary materials gives an example of flood hazard maps for RP100 under present-day climate and RCP 8.5 climate change scenarios. To quantify the impact of various climate change scenarios on the overall flood risk, simulations are conducted under both present-day climatic conditions and for two different climate scenarios, RCP4.5 and RCP8.5 (Meinshausen et al. 2011). To simulate the surface water flows during precipitation, we used the EU-DEM as input to the MIKE 21 overland flow model. The EU-DEM has a spatial resolution of $25 \mathrm{~m}$ and is freely available for the European continent (EEA 2013).

Two alternative sets of assumptions on soil infiltration values were applied to the hydrological model, which also increased the total number of flood model runs to 26 . One scenario uses uniform soil infiltration rates for all locations, while another uses location-specific values with different values for each grid cell. Both infiltration data sets (uniform and locationspecific) are calculated based on data for Denmark on the hydraulic conductivity of the upper soil layer (0-25 cm) in fully saturated soils (Kortforsyningen 2017a). In a city like Odense, actual infiltration rates are relatively low in the city center, primarily due to the presence of high areas with impervious surfaces, leading to high runoff levels for a given precipitation event. On the other hand, the outskirts of the city have lower building densities (and thus 
degrees of imperviousness) and will be characterized by relatively low runoff rates compared to those for the city center.

Using uniform infiltration values for the whole city results in the level of flooding in the city center of Odense being under-estimated, and vice versa in the outskirts of the city. City centers are often characterized by compacted soils and higher proportions of impervious surfaces compared to surrounding areas (peri-urban areas or city outskirts), both resulting in elevated runoff volumes during heavy precipitation in central parts of many major cities (Weng 2001; Yang and Zhang 2011). On this basis, assuming equal infiltration capacities for an entire urban area does not accurately reflect the capacity of the surface to infiltrate water, resulting in underestimates of flooding in the city center. This is problematic for decision-making regarding investments in adaptation measures, as it implies that damage estimates do not accurately reflect flooding at different locations. In addition, the difference in simulated flood levels when using detailed and coarse infiltration data will influence economic assessments of building losses derived from spatial damage cost assessments and flood hazard maps. Using detailed spatial information on infiltration rates therefore reduces the decision-making range in the cascade of uncertainties.

\subsection{Damage modeling and scenarios}

Assessing the damage costs of flooding in Odense involves a structural development of the damage cost model in relation to building damage costs. Here, we compare the application of uniform building property values per square meter flooded house area with location-specific values reflecting the actual property values and what is potentially at stake in the case of flooding. Location-specific information on flooding damage is a key input to decision-making on adaptation options (Chambwera et al. 2014). Two alternative sets of assumptions have been used for the building values in the damage function: uniform property values for all buildings are assumed in one scenario, while location-specific property values in the flooded areas are used in the other scenario. The building property values are provided by the Danish Nature Agency under the Ministry of Environment and Food of Denmark (Kortforsyningen 2017b). The values of individual buildings in the database are summarized as $100 \times 100 \mathrm{~m}$ grid cells to maintain confidentiality (Fig. 4). Building values are calculated from the official property valuations of the Danish Tax Authority (Danish Tax Authority 2017). To benefit from the higher resolution of the flood hazard maps, we calculated the average building value per square meter for each $100 \times 100 \mathrm{~m}$ grid cell prior to the overlay analysis of the flood maps with the building value data.

Figure 4 gives the property values of buildings in different parts of Odense. It shows a large difference between the values in the central parts of Odense compared with the outskirts. This relationship between city-center proximity and property values is representative of property values in many cities both in Europe and globally (EUROSTAT 2017). The damage model is based on a comprehensive assessment by Kaspersen and Halsnæs (2017) of the flooding damage to a range of assets in Odense, including buildings, health, transport infrastructure, cultural and historical assets, and ecosystems.

Damage costs are calculated by means of a two-step procedure in the damage cost model. Initially, we combine flood hazard maps, showing the depth and extent of flooding during specific events, with information on the locations and areas of individual buildings. The resulting output is an estimate of the total area of buildings flooded, with specific inundation depths. This information is then combined with a depth-damage function for buildings in 


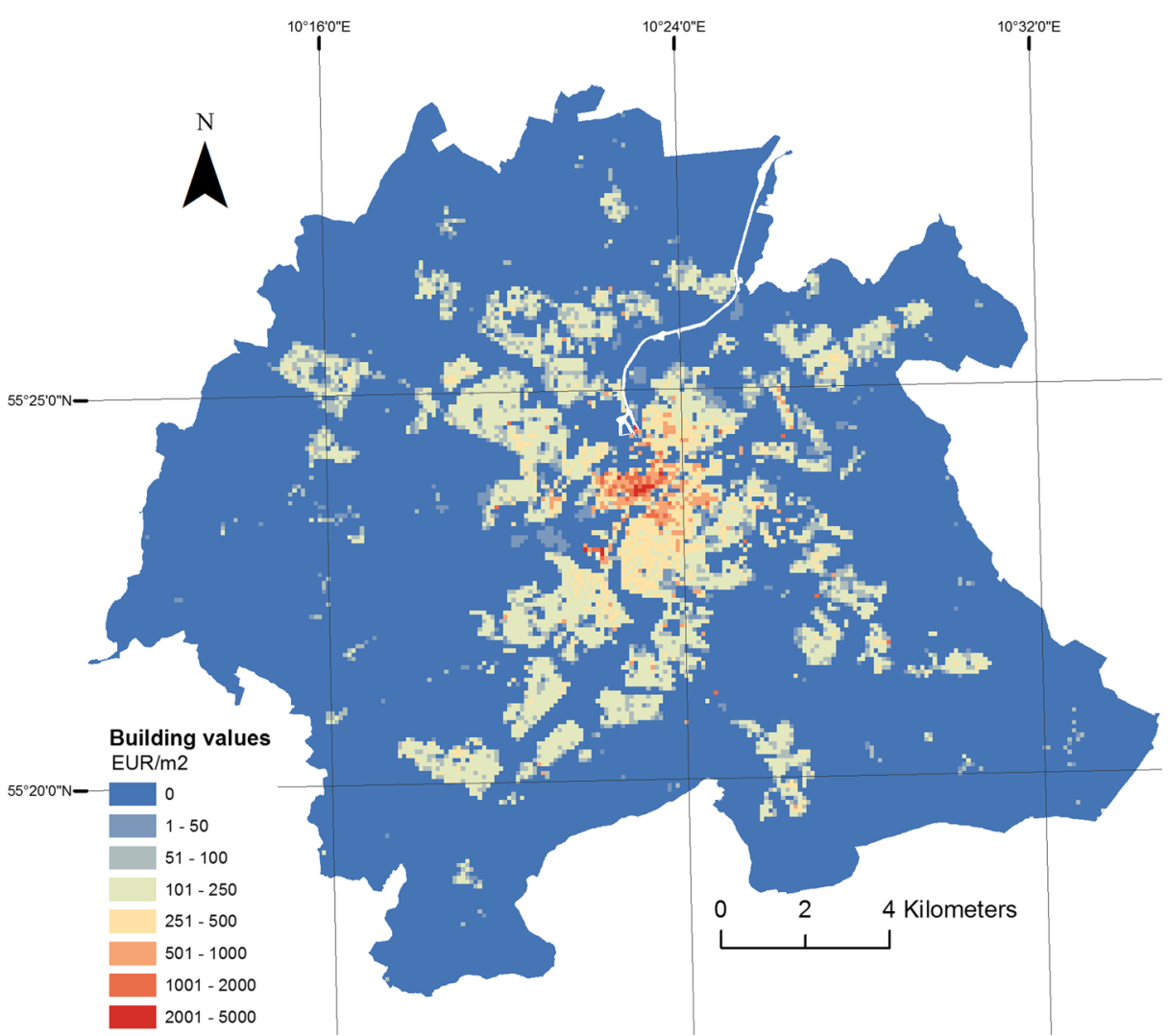

Fig. 4 Building values $\left(E U R / \mathrm{m}^{2}\right)$ for the city of Odense, averaged for $100 \times 100 \mathrm{~m}$ grid cells (data description: Klimatilpasning.dk (2017); data download: Kortforsyningen (2017b))

Denmark to estimate the total damage costs to buildings. Finally, we assume that flood damage to buildings does not begin until an inundation depth of $10 \mathrm{~cm}$ is reached, and that the damage percentage increases logarithmically toward a maximum of $\approx 80 \%$ for $\geq 450 \mathrm{~cm}$ of surface water. The depth-damage function applied here is in line with the findings of Jongman et al. (2012), who observed a similar relationship between inundation depth and maximum damage for urban areas in Europe. Figure 5 gives the damage costs caused by inundated areas in Odense during an extreme precipitation event corresponding to a 100-year return period under present-day climatic conditions. A maximum intensity of approximately $40 \mathrm{~mm} / \mathrm{h}$ and a total volume of rainfall of $59 \mathrm{~mm}$ characterize this precipitation event. The difference in damage cost estimates associated with our scenarios for uniform (Fig. 5a) versus location-specific (Fig. 5b) building properties is illustrated in Fig. 5c.

In terms of the geographical location of the two different damage cost scenarios, we find a clear tendency to underestimate damage in the central parts of Odense, and vice versa for the outer parts of the city (see Fig. 5 and Fig. S2 in supplementary materials), compared with estimates based on data for location-specific building property values. Using location-specific building property values rather than uniform values for Odense changes the damage cost estimate by $-11-1 \%$ depending on the type of infiltration data used (see Table S2 in supplementary materials). 


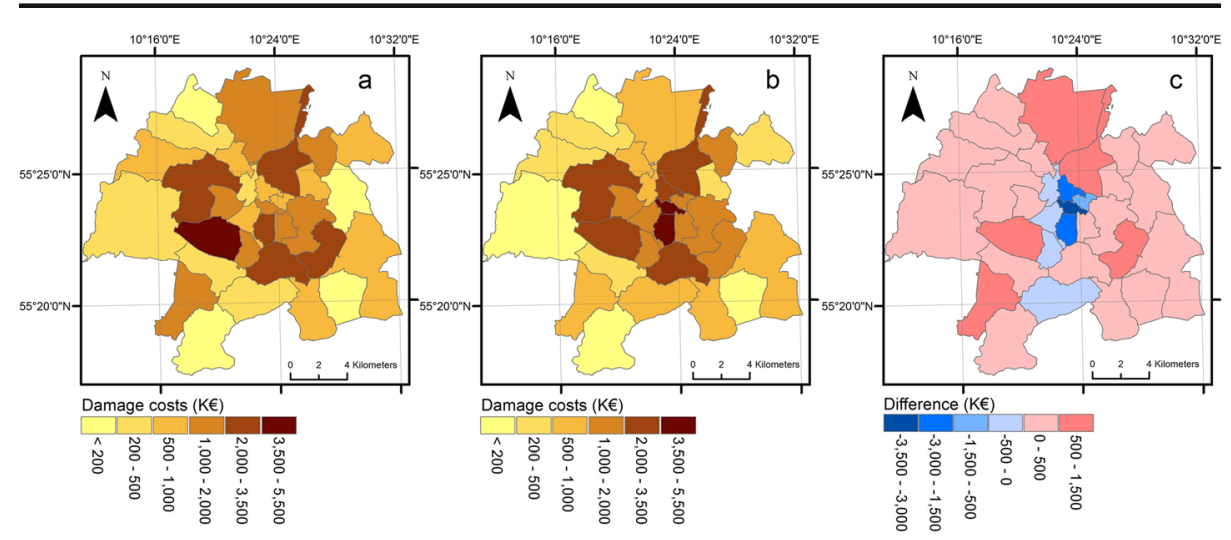

Fig. 5 Flood damage costs to buildings during present-day extreme precipitation using location-specific infiltration rates with a return period of 100 years using a uniform buildings values, b location-specific buildings values, and $\mathbf{c}$ the difference (average minus specific) in damage costs between using average and specific buildings values. Flood damage costs for blue-colored areas are underestimated when using average building values, and conversely for red-colored areas

The total damage cost for the flooding event is (a) $38.2 \mathrm{M} €$ when using uniform building property values and (b) $39.3 \mathrm{M} €$ when using location-specific building property values. The relatively small variation in total damage costs found in the two alternatives can partly be explained by the limited elevation differences in Odense, implying that flooding during extreme precipitation will be widespread across the entire urban area and will thus include areas with both high and low building values. The total damage cost estimate for the entire city, however, is not the most important information for decisionmaking purposes, since optimal investments should reflect the fact that the adaptation costs of a location-specific measure are less than or equal to the associated damage reduction for that specific area.

Comparing the damage cost estimates based on the different types of infiltration data reveals an increase in damage costs of 9-23\% when using location-specific infiltration data compared to using uniform values. There will, however, be larger local differences. Adding up over- and underestimated damage costs tends to even out substantial local differences, which are important when damage cost estimates are used as a basis for adaptation decisions for different parts of the city (Fig. 5). As a result, key uncertainties for decision-making may be masked.

\section{Decomposing the cascade of uncertainties in estimating flood damage costs for buildings in Odense}

Based on the scenarios for extreme precipitation outlined in Sections 3.2 and 3.3, flood damage to buildings was assessed by combining flood hazard maps (Fig. S1 in supplementary materials) with a depth-damage function and information on location-specific building values. We will now decompose the uncertainty ranges of the associated damage cost estimates for the range of uncertainties estimated in Sections 3.2-3.4.

Figure 6 shows the damage cost range, assuming that the present-day climate continues, for the RCP 4.5 and RCP 8.5 scenarios in the short, medium, and long terms 
respectively. The high/low climate factors (gray/black colored dots) refer to the lowest/ highest changes in precipitation intensities in RCP 4.5 and RCP 8.5 combined (the"RCP4.5 and RCP8.5" columns in Table S1 in the supplementary material show the combined range). The four gray and black dots represent the different combinations of infiltration and building property values. The full range is calculated using the 10th and 90th percentiles of the projected changes in precipitation intensities, which represent low and high climate change respectively, combined with all combinations of infiltration and building property value data (the error bars in Fig. 3 highlight the 10th and 90th percentiles). The "best guess" is calculated using the best available infiltration and building property value data combined with the full range of climate factors (10th to 90th percentiles). In general, we find that flood damage increases over time, as does the uncertainty in the climate projections, especially in the longer term, reflecting that the variation between climate models (GCMs) and scenarios (RCPs) increases over time. This implies that the differences in damage costs between low and high climate change factors increase toward the end of the century compared with the short term. The results of the analysis of flood damage to buildings show a full range of damage costs of $43.3 \mathrm{M}$ EUR to $87.2 \mathrm{M}$ EUR in the long term (2081-2100) compared to 27.0 to 59.9 EUR in the near future (2016-2035) for the RP100 precipitation event (Fig. 6). The full-range mean increases from 43.1 to $65.1 \mathrm{M}$ EUR during the same period. It should be noted that the lower range of the damage cost estimate has a slightly higher value when the time horizon of the analysis goes up to 2100 , but the major difference compared with a shorter time perspective is that the high end of the damage cost estimates increases dramatically over time. This reflects the large increase in the occurrence and intensity of precipitation events over time. Returning to the discussion in Section 2.2 "Decomposing the cascade of uncertainties," it is worth considering how much of the total cascade of uncertainties illustrated conceptually in Fig. 2a and b which has actually been reduced in the analysis of the Odense case study. One way to determine this is to assess how the range of flood damage estimates is affected in the context of the assumptions we have applied in our case study.

Damage costs were calculated for each climate scenario, time horizon, and alternative applications of the hydrological model and the damage cost model. The result is a pair of alternative combinations of assumptions about precipitation events, uniform versus location-specific infiltration rates, and uniform versus location-specific building property values. If we then consider the combined use of assumptions about location-specific infiltration rates and location-specific building property values as the "best-guess" estimate of damage costs, based on Fig. 6, we can identify how much our decomposition approach has reduced the damage cost uncertainty. This is illustrated in Table 1, where the reduced range is called a "best-guess" range. Table 1 also shows that the damage cost range achieved by applying our decomposition approach indicates that the "best-guess" range of the estimates increases the lower end of the damage costs compared with the "full range." The "best-guess" mean is approximately $7-8 \%$ higher than the full-range mean. For all time horizons, the decomposition approach reduces the focal range of damage cost estimates by approximately 7-9 M EUR (the difference between the fullrange and best-guess range columns in Table 1). This corresponds to a reduction of 20 $24 \%$ of the range compared with the full range. In addition, we examined the impact of the uncertainties of individual parameters on the variation in the full range of damage costs: that is, uncertainties in climate change, infiltration, and building property values 


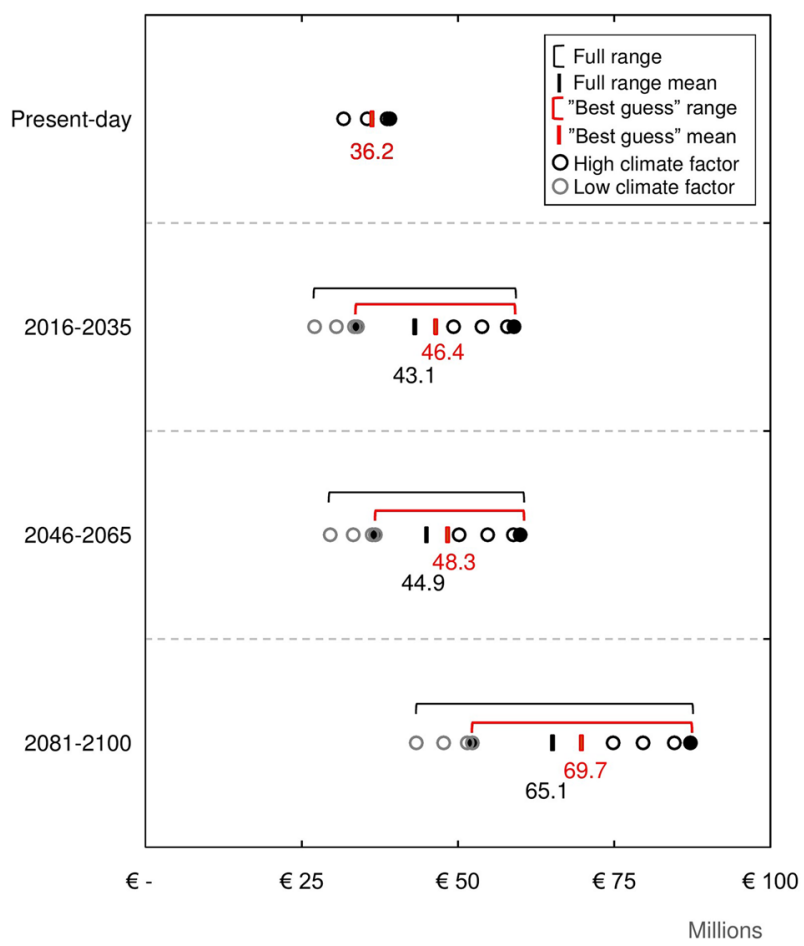

Fig. 6 Variation in damage costs to buildings during flooding from extreme precipitation with a 100-year return period (RP100) using different assumptions about the time horizon of climate change scenarios, climate model projections, building property values, and infiltration data. Damage costs are estimated for four periods: present-day, 2016-2035, 2046-2065, and 2081-2100. The individual circles represent different assumptions regarding climate scenario and models, building property values, and infiltration. Gray/black circles represent a low/high degree of climate change and refer to the lowest/highest values in precipitation intensity in the "RCP4.5 and RCP8.5" column in Table S1 in the supplementary material, which represent the 10th and 90th percentiles of the ten GCMs. The solid gray and black circles highlight the "best-guess" estimates for building damage costs, where location-specific building values and location-specific infiltration are used. The "best-guess" range is shown as the variation between the solid gray and black circles, while the full range represents the total variation of all estimates

(Table 1). The climate change scenarios are the largest contributor to the uncertainty of the damage cost estimates, and the relative importance of this factor increases strongly with time. Assumptions about infiltration rates are the second most important factor, but there is no time factor built into our analysis either for this factor or for the building property value factor.

Climate scenario uncertainties are particularly important to draw to the attention of decision-makers when adaptation options with a long lifetime and inflexible designs are being considered. Furthermore, it is important to recognize that future trends in city development and thus the vulnerability and values of different assets have not been taken into consideration in our approach due to difficulties in establishing future scenarios for location-specific city activities. Such city development scenarios should include a dynamic development of the assumptions about infiltration rates and building property values over time to reflect trends in city development and economic growth. 
Table 1 Damage cost estimates for buildings in Odense for different time horizons and assumptions regarding climate change, infiltration, and building property values corresponding to Fig. 6 . The full range is calculated with the 10th (low) and 90th (high) percentiles of the climate factors. The best-guess range is the estimated damage costs when using location-specific infiltration/building property values together with low/high climate factors respectively (range within the damage cost estimates marked with black circles in Fig. 6). The impacts of parameter uncertainties are calculated as the total variation in damage estimates when using location-specific compared to average values for infiltration and building property values and low/high climate factors (climate change). Percentages in brackets are the share of the total variation for each parameter; climate change, infiltration, and building property values

\begin{tabular}{|c|c|c|c|c|c|}
\hline & \multirow[t]{2}{*}{ Full range } & \multirow[t]{2}{*}{$\begin{array}{l}\text { "Best-guess" } \\
\text { range }\end{array}$} & \multicolumn{3}{|c|}{$\begin{array}{l}\text { Impact of parameter uncertainties on variations in full } \\
\text { range of damage costs }\end{array}$} \\
\hline & & & Climate change & Infiltration & $\begin{array}{l}\text { Building property } \\
\text { values }\end{array}$ \\
\hline $\begin{array}{l}\text { Continuation of } \\
\text { present climate }\end{array}$ & 31.7-39.1 M€ & $39.1 \mathrm{M} €$ & - & $5.3 \mathrm{M} €(71 \%)$ & $2.1 \mathrm{M} €(29 \%)$ \\
\hline $\begin{array}{l}\text { Short-term climate } \\
\text { change 2016-2035 }\end{array}$ & $27.0-58.9 \mathrm{M} €$ & $33.9-58.9 \mathrm{M} €$ & $23.6 \mathrm{M} €(74 \%)$ & $5.9 \mathrm{M} €(18 \%)$ & $2.4 \mathrm{M} €(8 \%)$ \\
\hline $\begin{array}{r}\text { Medium-term climate } \\
\text { change } 2046-2065\end{array}$ & $29.5-59.9 \mathrm{M} €$ & $36.8-59.9 \mathrm{M} €$ & $21.9 \mathrm{M} €(72 \%)$ & $6.0 \mathrm{M} €(20 \%)$ & $2.5 \mathrm{M} €(8 \%)$ \\
\hline $\begin{array}{l}\text { Long-term climate } \\
\text { change } 2081-2100\end{array}$ & 43.3-87.2 M€ & $52.3-87.2 \mathrm{M} €$ & $33.2 \mathrm{M} €(76 \%)$ & $7.5 \mathrm{M} €(17 \%)$ & $3.1 \mathrm{M} €(7 \%)$ \\
\hline
\end{tabular}

\section{Conclusions}

This paper has identified critical analytical steps and assumptions that can help select and understand the uncertainties surrounding the damage cost estimates that are most relevant to key decision-making issues on urban flooding risks from extreme precipitation. The approach has been applied to a case study of flooding caused by extreme precipitation in the city of Odense. Decision-making as a framing of uncertainty analysis lays down its own context-specific boundaries for the uncertainties, which is important to address. In the case of urban flooding, the short- to medium-term time frame is important to decision-makers, and the uncertainty range arriving from climate scenarios and models is relatively small compared with longer time frames. Some adaptation measures, however, have a long lifetime and are difficult to adjust over time, and it is in this case important to take a wider range of uncertainties spanning a longer time frame of climate models and RCPs into consideration. Adding more detailed location-specific data on soil infiltration rates to the hydrological model and location-specific building property values further reduces the cascade of uncertainties surrounding damage cost estimates. Including more accurate localized information on flooding and damage costs can be particularly important in making subsequent assessments of the adaptation options to be implemented in specific areas in order to meet the criteria of cost-effectiveness. In the specific configuration of our uncertainty decomposition exercise, the climate scenario range proved to be a very important uncertainty component in the long term. Finally, it should be recognized that the cascade of uncertainties considered in this paper is only a subset of the full range of uncertainties surrounding risk estimates. Some very basic assumptions used in estimating damage costs, like the choice of discount rate and the monetary values applied to damage estimates, will also imply an increase in the cascade of uncertainties, which would be very relevant to consider in more detail in relation to decision-making on climate change adaptation. Furthermore, major uncertainties also arise from the dynamic trends in city development that influence asset values and infiltration rates. 
Acknowledgements The authors thank Jakob Luchner and Nina Donna Domingo of DHI for assisting with the extreme value analysis and for technical support in constructing and running the MIKE 21 overland flow model.

Publisher's Note Springer Nature remains neutral with regard to jurisdictional claims in published maps and institutional affiliations.

\section{References}

Chambwera M, Heal G, Dubeux C, Hallegatte S, Leclerc L, Markandya A, McCarl BA, Mechler R, Neumann JE (2014) Economics of adaptation. In: Climate change 2014: impacts, adaptation, and vulnerability. Part A: global and sectoral aspects. Contribution of Working Group II to the Fifth Assessment Report of the Intergovernmental Panel on Climate Change. In: Field CB, Barros VR, Dokken DJ, Mach KJ, Mastrandrea MD, Bilir TE, Chatterjee M, Ebi KL, Estrada YO, Genova RC, Girma B, Kissel ES, Levy AN, MacCracken S, Mastrandrea PR, White LL (eds) . Cambridge University Press, Cambridge, United Kingdom and New York, pp 945-977

Climate Policy Initiative (2017) Global landscapes of climate finance, https://climatepolicyinitiative. org/publication/global-landscape-of-climate-finance-2015/. Accessed 22 March 2017

Cubasch, U., D. Wuebbles, D. Chen, M.C. Facchini, D. Frame, N. Mahowald, and J.-G. Winther, 2013: Introduction. In: Climate change 2013: the physical science basis. Contribution of Working Group I to the Fifth Assessment Report of the Intergovernmental Panel on Climate Change [Stocker, T.F., D. Qin, G.-K. Plattner, M. Tignor, S.K. Allen, J. Boschung, A. Nauels, Y. Xia, V. Bex and P.M. Midgley (eds.)]. Cambridge University Press, Cambridge, United Kingdom and New York, NY, USA

Danish Tax Authority (2017) Ejendomsvurdering. http://www.vurdering.skat.dk/Ejendomsvurdering. Accessed 2017

DHI (2017) MIKE 21 - powered by DHI. https://www.mikepoweredbydhi.com/products/mike-21

EEA (2013) Digital elevation model over Europe (EU-DEM), European Energy Agency. http://www.eea.europa. eu/data-and-maps/data/eu-dem. Accessed 24 August 2017

ESGF (2016) WCRP CORDEX. https://esgf-node.ipsl.upmc.fr/search/cordex-ipsl/. Accessed 15 January 2016

European Environment Agency (2017) Climate change, impacts and vulnerability in Europe 2016: an indicatorbased report

EUROSTAT (2017) Statistics on European cities. http://ec.europa.eu/eurostat/statistics-explained/index. php/Statistics_on_European_cities\#Average_price_of_houses. Accessed 2017

Fereday D, Chadwick R, Knight J, Scaife AA (2018) Atmospheric dynamics is the largest source of uncertainty in future winter European rainfall. J Clim 31:963-977. https://doi.org/10.1175/JCLI-D-17-0048.1

Field CB, Barros V, Stocker TF, Qin D, Dokken DJ, Ebi KL, Mastrandrea MD, Mach KJ, Plattner GK, Allen SK, Tignor M, Midgley PM (2012) Managing the risks of extreme events and disasters to advance climate change adaption: a special report of working groups I and II of the intergovernmental panel on climate change. Cambridge University Press, New York

Halsnæs K, Kaspersen P, Drews M (2015) Key drivers and economic consequences of high end climate scenarios: uncertainties and risks. Clim Res. https://doi.org/10.3354/cr01308

Haasnoot M, Kwakkel JH, Walker WE, ter Maat J (2013) Dynamic adaptive policy pathways: a method for crafting robust decisions for a deeply uncertain world. Glob Environ Change 23:485-498. https://doi. org/10.1016/j.gloenvcha.2012.12.006

Hawkins E, Sutton R (2011) The potential to narrow uncertainty in projections of regional precipitation change. Clim Dyn 37:407-418. https://doi.org/10.1007/s00382-010-0810-6

Hawkins E, Sutton R (2009) The potential to narrow uncertainty in regional climate predictions. Bull Am Meteorol Soc 90:1095-1107. https://doi.org/10.1175/2009BAMS2607.1

Intergovernmental Panel on Climate Change (Ed.) (2014) Climate Change 2013: The physical science basis. Working group I Contribution to the Fifth Assessment Report of the Intergovernmental Panel on Climate Change. Cambridge University Press, Cambridge

Jongman B, Kreibich H, Apel H, Barredo JI, Bates PD, Feyen L, Gericke A, Neal J, Aerts JCJH, Ward PJ (2012) Comparative flood damage model assessment: towards a European approach. Nat Hazards Earth Syst Sci 12: 3733-3752. https://doi.org/10.5194/nhess-12-3733-2012

Kaspersen P, Fensholt R, Drews M (2015) Using Landsat vegetation indices to estimate impervious surface fractions for European cities. Remote Sens 7:8224-8249. https://oi.org/10.3390/rs70608224

Kaspersen PS, Halsnæs K (2017) Integrated climate change risk assessment: a practical application for urban flooding during extreme precipitation. Clim Serv. https://doi.org/10.1016/j.cliser.2017.06.012 
Kent C, Chadwick R, Rowell DP (2015) Understanding uncertainties in future projections of seasonal tropical precipitation. J Clim 28:4390-4413. https://doi.org/10.1175/JCLI-D-14-00613.1

Klimatilpasning.dk (2017) Værdikort [value map]. http://www.klimatilpasning.dk/kommuner/kortlaegning-tilbrug-for-klimatilpasning/den-kommunale-risikokortlaegning/vaerdikort.aspx. Accessed 17 July 2017

Kortforsyningen.dk (2017a) Nedbør: Hydraulisk ledningsevne. https://download.kortforsyningen. $\mathrm{dk} /$ content/nedb\%C3\%B8r-hydraulisk-ledningsevne. Accessed 17 July 2017

Kortforsyningen.dk (2017b) Værdikort for bygninger. https://download.kortforsyningen.dk/content/v\%C3\%A6 rdikort-v\%C3\%A6rdikort-bygninger. Accessed 17 July 2017

Madsen MS, Langen PL, Boberg F, Christensen JH (2017) Inflated uncertainty in multimodel-based regional climate projections: inflated uncertainty. Geophys Res Lett 44:11,606-11,613. https://doi.org/10.1002/2017 GL075627

Maraun D (2013) When will trends in European mean and heavy daily precipitation emerge? Environ Res Lett 8(1):014004. https://doi.org/10.1088/1748-9326/8/1/014004

Meinshausen M, Smith SJ, Calvin K, Daniel JS, Kainuma MLT, Lamarque JF, Matsumoto K, Montzka SA, Raper SCB, Riahi K, Thomson A, Velders GJM, van Vuuren DPP (2011) The RCP greenhouse gas concentrations and their extensions from 1765 to 2300. Clim Chang 109:213-241. https://doi.org/10.1007 /s10584-011-0156-Z

Moss RH, Schneider SH (2000) Uncertainties in the IPCC TAR: recommendations to lead authors for more consistent assessment and reporting. In: Pachauri R, Taniguchi T, Tanaka K (eds) Guidance papers on the cross cutting issues of the third assessment report of the IPCC. World Meteorological Organization, Geneva, pp 33-51

Munich RE (2017): Topics geo - natural catastrophes (2016) analyses, assessments, positions 2017 issue

Sanford T, Frumhoff PC, Luers A, Gulledge J (2014) The climate policy narrative for a dangerously warming world. Nat Clim Chang 4:164

Santos JA, Belo-Pereira M, Fraga H, Pinto JG (2016) Understanding climate change projections for precipitation over western Europe with a weather typing approach: precipitation projections for Europe. J Geophys Res Atmospheres 121:1170-1189. https://doi.org/10.1002/2015JD024399

Schneider SH (1983) CO $^{2}$ climate and society: a brief overview. Social science research and climate change an interdisciplinary appraisal. Springer Verlag

Skougaard Kaspersen P, Høegh Ravn N, Arnbjerg-Nielsen K, Madsen H, Drews M (2017) Comparison of the impacts of urban development and climate change on exposing European cities to pluvial flooding

Stocker TF, Qin D, Plattner GK, Alexander LV, Allen SK, Bindoff NL, Bréon FM, Church JA, Cubasch U, Emori S, Forster P, Friedlingstein P, Gillett N, Gregory JM, Hartmann DL, Jansen E, Kirtman B, Knutti R, Krishna Kumar K, Lemke P, Marotzke J, Masson-Delmotte V, Meehl GA, Mokhov II, Piao S, Ramaswamy V, Randall D, Rhein M, Rojas M, Sabine C, Shindell D, Talley LD, Vaughan DG and Xie SP (2013) Technical summary. In: Climate change 2013: the physical science basis. Contribution of Working Group I to the Fifth Assessment Report of the Intergovernmental Panel on Climate Change [Stocker TF, Qin D, Plattner GK, Tignor M, Allen SK, Boschung J, Nauels A, Xia Y, Bex V and Midgley PM (eds)]. Cambridge University Press, Cambridge, United Kingdom and New York, NY, USA

Sunyer MA, Hundecha Y, Lawrence D, Madsen H, Willems P, Martinkova M, Vormoor K, Bürger G, Hanel M, Kriaučiūnienė J, Loukas A, Osuch M, Yücel I (2015) Inter-comparison of statistical downscaling methods for projection of extreme precipitation in Europe. Hydrol Earth Syst Sci 19:1827-1847. https://oi. org/10.5194/hess-19-1827-2015

van den Hoek RE, Brugnach M, Mulder JPM, Hoekstra AY (2014) Analysing the cascades of uncertainty in flood defence projects: how "not knowing enough" is related to "knowing differently". Glob. Environ. Change 24:373-388. https://doi.org/10.1016/j.gloenvcha.2013.11.008

Weitzman ML (2011) Fat-tailed uncertainty in the economics of catastrophic climate change. Rev Environ Econ Policy 5:275-292. https://doi.org/10.1093/reep/rer006

Weng Q (2001) Modeling urban growth effects on surface runoff with the integration of remote sensing and GIS. Environ Manag 28:737-748. https://doi.org/10.1007/s002670010258

Wilby RL, Dessai S (2010) Robust adaptation to climate change. Weather 65:180-185. https://doi.org/10.1002 /wea.543

Willems P, Olsson J, Arnbjerg-Nielsen K, Beecham S, Pathirana A, Gregersen I.B, Madsen H, Nguyen V (2012) Impacts of climate change on rainfall extremes and urban drainage systems. IWA, London

Yang J-L, Zhang G-L (2011) Water infiltration in urban soils and its effects on the quantity and quality of runoff. J Soils Sediments 11:751-761. https://doi.org/10.1007/s11368-011-0356-1

Zhang X, Zwiers FW, Li G, Wan H, Cannon AJ (2017) Complexity in estimating past and future extreme shortduration rainfall. Nat Geosci 10:255-259. https://doi.org/10.1038/ngeo2911 